1 Organic farming: An exploratory study based on evidence from Bangladesh

\title{
Organic Farming: to Pursue or Not to Pursue? An exploratory study based on evidence from Bangladesh
}

\author{
By RUBAIYA MURSHED ${ }^{1} \&$ MOHAMMAD RIAZ UDDIN $^{2}$
}

Keywords: Consumer perception; environment; health; income level; organic farming

In the field of agricultural food production, the transition between organic and inorganic farming methods has been an issue of much debate. The debate, on one hand, stresses the urgency for the transition in order to preserve environment and health; and, on the other hand, emphasizes the pressure of maintaining food production for a large growing population. Thus, the dilemma is how to find an agricultural system that would balance between obtaining food security and ensuring a safe sustainably environment-friendly food production system. This article focuses on the debate, in the context of Bangladesh, and questions whether it is the proper time, and stage in the development process, to attempt the transition from inorganic conventional food production methods to organic food production methods. This article contemplates why the organic rice market is not expanding in Bangladesh, and attempts to explain the slow growth of the market through the two main factors of income constraint and lack of awareness among people about the environmental and health detriments of inorganic farming methods. The study is exploratory in nature, and finds that it is not mainly the lack of awareness but the income constraint that can be principally attributed to the slow expansion of the organic rice market in Bangladesh. Through exploring consumers' awareness about organic farming methods and their demand for organic products, this study shows how income as the major constraint, besides price, affects consumers demand for organic and inorganic rice in Bangladesh. Income being identified as the major barrier reveals the potential of the organic rice market to grow in the future, as Bangladesh continues its journey towards becoming a middle-income country.

Agricultural food production methods and farming processes have evolved over time with the advancement of science and technology. These methods and processes may vary across countries, climates and geographical locations. The debate circling the transition from conventional food production methods, which use chemical fertilizers and insecticides, to organic food production methods has been a universally researched issue.

\footnotetext{
${ }^{1}$ MPhil, University of Cambridge, 2016/17'.

Email ID: rubaiyamurshed@gmail.com

(Corresponding author)

${ }^{2}$ Research Associate, Bangladesh Institute of Development Studies [BIDS], Bangladesh.

Email ID: riazbids@gmail.com
} 
2 Organic farming: An exploratory study based on evidence from Bangladesh

Food production methods that involve the use of chemical fertilizers and pesticides, especially for commercialized purposes, are known as 'conventional or inorganic' food production methods (K.Kumari, Kumar, \& Rao, 2014). Although there are some controversies regarding the magnitude of the negative effect, on human health, from using chemical elements in food production (Magnusson, Arvola, Hursti, Åberg, \& Sjödén, 2003; D. Bourn \& Prescott, 2002)- different research has unanimously revealed that applying such fertilizers and pesticides pose a threat to the environment (Camargo \& Á.Alonso, 2006; Scialabba \& Hattam, 2002; B.C. Ghosh \& Bhat, 1998). According to several studies, the increased use of chemical fertilizers, insecticides and pesticides leads to environmental degradation, and adversely affects aquatic life, livestock and people's health (Asaduzzaman, 1996; Hossain, Salam, \& Alam, 1994; Hossain \& Kashem, 1997; Rahman $\&$ Thapa, 1999). Several studies show that the excessive usage of agro-chemicals might lead to higher production costs and could also increase the decline in soil productivity, contamination of surface and ground water, and could have severe adverse effects on both human and animal health (Biswas, 1994; Edwards, 1989). Additionally, research shows that using excessive pesticides and chemicals in fertilizing soil could affect the entire eco-system, starting from the land, plants and trees to the insects, fish, animals etc. (Dwyer, et al., 1997; Newcombe \& MacDonald, 1991). For example, the chemicals used in conventional farming have often been reported to seep into the nearby water bodies, causing water contamination; which in turn harms the fish residing in the water bodies (Heath, 1995).

There is a growing need for a sustainable agricultural system which is not harmful, especially for the sake of the environment and for health. Hansen (1996) suggests that there is a growing need for sustainable organic agriculture in response to concerns about the adverse impacts of conventional agriculture (Hansen, 1996). Yunlong and Smith (1994) suggest that the sustainability of an agricultural system should be assessed from 'the perspectives of ecological soundness, social acceptability, and economic viability'. They define 'Ecological soundness' as the preservation of the natural environment; 'Economic viability' as the maintenance of yields and productivity of crops and livestock; and 'social acceptability' as equality and improved quality of life (Yunlong \& Smith, 1994). An alternative to conventional agriculture, especially to genetically modified agriculture methods, is 'organic agriculture' (also normally known as ecological agriculture), which emphasizes the reduced use of agro-chemicals, and promotes the increased use of local, natural, organic and on-farm resources in order to make the agricultural system environmentally and economically sustainable (Akter, 1997). According to Rasul and Thapa (2004), "Organic/ecological agriculture has the potential towards becoming ecologically, economically and socially more sound than conventional agriculture, as it requires considerably less agrochemicals".

Organic farming methods usually avoid the high dosage of chemical pesticides and fertilizers used in conventional farming methods (Pimentel, Hepperly, Hanson, Douds, \& Seidel, 2005). 
3 Organic farming: An exploratory study based on evidence from Bangladesh

According to the International Federation of Organic Agriculture Movements (IFOAM, 2006), "Organic agriculture is a production system that sustains the health of soils, ecosystems and people". Some research has provided evidence to believe that organic farming methods are healthier because of "higher antioxidant concentrations, lower cadmium concentrations and lower pesticide residues in organically grown crops" (Barański, et al., 2014); while it has been proven that it is the best farming method option for the preservation of the nature and environment (Pimentel, Hepperly, Hanson, Douds, \& Seidel, 2005). According to the Ministry of Agriculture, Food and Rural Affairs in Canada, organic farming involves not using chemical pesticides, chemical artificial fertilizers, genetically modified organisms, antibiotics and growth hormones (Martin, 2009). The Department for Agriculture and Rural Affairs (DEFRA) suggests that organic food production avoids the use of man-made fertilisers, pesticides; growth regulators and livestock feed additives; and the use of genetically modified organisms (GMOs) which are generally prohibited by organic legislation (DEFRA). In this study, the term 'organic' is referred to as a system in which artificial chemical pesticides and fertilizers are generally avoided in crop production or used in a minimum amount compared to the amount used in conventional agriculture. For example, in this study- organic rice is considered to be rice that is produced using mostly natural fertilizers and pesticides, instead of artificial chemical ones. On the other hand, it also refers to the type of rice that is produced more traditionally rather than using new and improved genetically modified production methods.

In Bangladesh, the transition between conventional and organic farming involves the consideration of food security; and the differences between the two food production methods are also important to explore and verify. Farmers are not likely to quickly shift to organic/ecological agricultural methods because their financial return is higher in conventional agriculture. According to Rasul and Thapa (2004), “Today's food security is more important than tomorrow's, so farmers' prime concern is increasing crop production". In Bangladesh, increased crop and food production has been incentivized by providing subsidies for intensified usage of chemical fertilizers, pesticides and irrigation equipment (Hossain M. , 1988). The study by Rasul and Thapa (2004) shows that farmers prefer using increased amounts of fertilizers in conventional farming because it usually gives them more crop yields. In interviews, farmers disclosed their fear that if the amount of chemical fertilizers applied in crop production was not increased, crop yields and subsequently food supply might decrease over time (Rasul \& Thapa, 2004).

In terms of the differences between the two food production systems, conventional and ecological/organic agricultural systems in Bangladesh differ in the usage, specifically in the dosage, of chemical fertilizers and insecticides. Majority of farmers using organic agricultural methods in Bangladesh apply some amount of chemical fertilizers, but their amount of usage is still significantly lower than the amount used by conventional farmers (Rasul \& Thapa, 2004). On the contrary, very few farmers in more organic agricultural systems apply chemical insecticides to 
4 Organic farming: An exploratory study based on evidence from Bangladesh

crops because they use their 'indigenous knowledge' to control insects by using herbal natural insecticides and traps. Thus, to some extent the organic/ecological agricultural system is environmentally more sustainable than the conventional agricultural system, mostly because the ecological system is less dependent on chemical inputs compared to the conventional system (Rasul \& Thapa, 2004). A study by Sattar and Mian (1999) found that majority of farmers in the conventional system, and a large portion of farmers in the ecological system as well, apply chemical fertilizers to their farmlands. The study found that the intensity of chemical fertilizer use is significantly higher in the conventional system than in the ecological system; and that farmers in the conventional system do not apply fertilizers in a balanced way. Through discussions with the farmers, the study found that farmers in the conventional system reported to have applied increasingly large amounts of chemical fertilizers over successive years in order to maintain crop yield, especially as a prerequisite against the gradual deterioration of soil quality caused by mainly the overuse of chemical fertilisers itself. Other studies have reported similar accounts from farmers in Bangladesh (Hossain and Kashem, 1997; Rahman and Thapa, 1999). On the other hand, Steila (1976) identified that perhaps one of the major problems in the conventional system is that farmers apply only chemical fertilizers to their farming, whereas farmers of comparatively more ecological agricultural methods use non-chemical organic fertilisers as well.

In the interest of environmental protection, sustainability in farming and food production and also the long-term wellbeing of human-beings- a few efforts have been made in Bangladesh to promote ecological agriculture as an alternative to conventional agriculture and genetically modified agriculture. In the process, research has been conducted to verify whether using a more ecological agriculture system might reap more benefits economically, environmentally and in terms of health conservation as well. A particular study by Rasul and Thapa (2004), through studying the ecological agriculture promotion program in Bangladesh for twelve years, found that ecological agriculture does not differ much from conventional agriculture in terms of land-use patterns, crop yields and food security. On the other hand, the study found that there is no significant difference between the two agricultural systems in financial and economic benefits, and in value addition. The study suggests that without alternative cost-effective ways of maintaining crop yields, farmers would find it difficult to reduce and abandon the use of chemicals in their crop production.

Moreover, despite the researched and proven benefits of organic farming methods, the organic food market is yet to overthrow the inorganic food market in size. In 2011, the size of the global market was recorded to be 54.9 billion USD; while the organic per capita consumption was 8 billion USD, with 24 countries having more than 5\% organic agricultural land (IFOAM Annual Report, 2010; Willer, Yussefi, \& Sorensen, 2010). In 2013, with gradual expansion, the global organic market was estimated to have reached a value of 72 billion USD (IFOAM \& FiBL, 2015).

In Bangladesh, organic farming still occurs mostly on an experimental basis. Organic cultivation in Bangladesh is estimated at 0.177 million hectares (IFOAM Annual Report, 2010), representing 
5 Organic farming: An exploratory study based on evidence from Bangladesh

only $2 \%$ of the country's total cultivable land. According to the IFOAM Annual Report (2010), out of the 138 NGOs that are members of the Forum of Regenerative Agriculture Movement (FORAM) in Bangladesh, only 47 are engaged in organic agriculture. There are only a few commercial organic crop suppliers in the capital city Dhaka - Proshika, Kazi Shahid Foundation, Meena Bazar and Shoshya Probortona. To attain food security, inorganic food production methods have been the sought solution for Bangladeshi policymakers since the nation's independence. For example, rice has been produced through 'genetically modified' food production methods to attain food security. Many different varieties of rice, such as 'Golden rice' (IRRI, 2015), has thus gained recognition in the process (Qaim \& Kouser, 2015). But soon after the recognition of the innovative brands of rice, the criticism of genetically modified food production processes arose (Whitman, 2000). Scepticism also arose on how food security could be compromising the nutrition status of people (Capone, Bilali, Debs, Cardone, \& Driouech, 2014). Since farmers often lack the knowledge about the correct dosage and usage of pesticides in farming, the risk of damages from pesticide and chemical fertilizer based genetically modified inorganic food production methods could be higher (Rahman \& Alam, 1997).

Acknowledging the fact that organic food production methods could be better for the health of the population and definitely for the conservation of the environment, this research dwells on the reasons behind the quite slow growth of the organic rice market size in Bangladesh. Regarding the slow growth of ecologically and organically farmed products, Rasul and Thapa (2004) suggest that most consumers in Bangladesh are still not much concerned about the health effects of chemicals-based product; and hypothesizes that organic agriculture might become economically viable in the future if health-conscious people would be willing to pay higher prices for crops produced with minimum or no chemical fertilizers and toxic insecticides (Rasul \& Thapa, 2004). According to the Kazi Shahid Foundation (Shamonti, 2012), the main reasons for organic farming not expanding in Bangladesh are the lack of support from the government and the lack of awareness of the citizens.

In understanding the demand for a particular product, the factors usually taken into consideration include the price of the product, the price of the substitute products, income of the consumers, purchasing power of the consumers, awareness of the consumers about the products, advertising of the product etc. (Whelan, Msefer, \& Chung, 2001). This research aims to understand whether the income constraint of consumers, alongside consumers lack of awareness about organic food production methods, is contributing to the rigidity of the organic market growth in Bangladesh. In theory and in reality, the price of organic products in the food market is usually higher than the same products produced inorganically, mainly because of the higher costs associated with organic production methods (The Daily Meal, 2012). It can be assumed that consumers with substantially higher levels of income would be more likely to purchase organic products, and consumers with income constraints would be less likely to purchase organic products despite their willingness to consume and their awareness. This research is based on the hypothesis that consumers' income 
6 Organic farming: An exploratory study based on evidence from Bangladesh

constraint is the main reason behind the slow growth of the organic rice market in Bangladesh, and that the market will not thrive unless consumers' income level increases. If this hypothesis is found to be true, it could lead to the contemplating of whether pursuing organic food production methods on a large scale in Bangladesh would be appropriate at the current stage of development, and especially with 3,190 PPP dollars income per capita recorded in 2013 (World Bank, 2013). With the middle-income country goal looming on the horizon, perhaps organic food production would be a more viable route to pursue in the near future once the income goal is reached. Previous research (Hughner, McDonagh, Prothero, Shultz, \& Stanton, 2007) has indicated consumers' low income level to be a barrier to organic production, especially in poorer countries; for example, organic foods are relatively unpopular with consumers in developing countries because of the higher prices of the organic products and the consumers' inability to purchase the higher priced organic products with their comparatively lower income levels. Moreover, market opportunities offer good incentives for practicing organic agriculture in high income countries, but insufficient incentives in low income countries. On the other hand, Yussefi and Willer (2005) argued that organic agriculture can be advantageous for poorer countries, besides being a solution just for richer countries, through contributing to purposeful and sustainable socio-economic and ecological development.

Besides consumers' income and product price, proper advertising of organic products is crucial. If consumers are not aware of the existence of a better substitute to inorganic products, such as organic products, and lack information about the availability of organic products- perhaps many consumers with the willingness to purchase the products, and the affordability, would miss the opportunity to purchase (Shafie \& Rennie, 2012). This study considers the possibility of consumers' lack of awareness being a strong reason behind the stiff growth of the organic rice market in Bangladesh. Several studies have highlighted the environmental awareness and health consciousness of consumers as major determinants to their shifting from inorganic products consumption to organic product consumption (Magnusson, Arvola, Hursti, Åberg, \& Sjödén, 2003; Yiridoe, Bonti-Ankomah, \& Martin, 2005). Sarker and Itohara (Sarker \& Itohara, 2008) showed in their study that consumers who were highly alert about their personal health were likelier to take the environmental hazards caused by agro-chemicals into account, to the extent that they would start purchasing more organic products in place of inorganic alternatives.

Supporting the fact that organic food production methods are ideal and more favourable for the betterment of peoples' health and especially for protecting the environment, this research analyses the demand for organic food by consumers in Dhaka, Bangladesh; and tries to explain whether it is logical for organic rice suppliers to expand their market in Bangladesh while consumers' income, in general, is quite low. The objectives of this research are: (1) Testing the awareness level of local consumers in Dhaka city about organic food products, (2) Identifying the preference criteria of organic and inorganic food consumers in Dhaka, which would reveal what factors are considered by consumers who choose between these two types of food products, (3) Exploring 
7 Organic farming: An exploratory study based on evidence from Bangladesh

the problems associated with the expansion of organic farming in Bangladesh, and testing the hypothesis that income is a major barrier to consumers' organic food consumption.

This research is explorative in nature because rather than attaining findings that can be generalized to reflect the population of Bangladesh, it provides evidence that perhaps the results could be relatable from the sample to the population, and stimulates the need for further research to be conducted on the topic. The reason behind this study being explorative is that the sample size is small compared to the population, and so the findings from the analyses of this sample would not be generalizable. So, although the findings of this study fit the sample data, namely shoppers at two markets that sell organic food products over the time period of three days- the findings cannot be claimed to reflect the perceptions and consumption patterns of the portion of the Bangladeshi population that has a preference for organic food products over conventionally farmed food products.

\section{Data and Methodology}

\section{Data collection}

The data was collected from grocery stores where organic food products are regularly available alongside inorganic food products. The two main organic food product selling stores in Dhaka city are Meena Bazar and Shoshya Probortona; and data for this research was collected from consumers shopping in these two stores during the period of 8 to 11 August 2012. Collecting data from those particular venues allowed for the data to incorporate consumers of both organic and inorganic food products; and also captured different income levels among the consumers. A survey questionnaire was designed to collect the desired data and the consumers were requested to spare 15 minutes of their grocery-shopping time to fill up the survey face-to-face with the researcher. Some consumers preferred filling up the survey questionnaire themselves and talked to the researcher about their answers through the process. Consumers who participated in the survey were given a 5\% discount by the stores, whose authority fully supported and encouraged the practice of researching consumer perceptions of organic food products in Bangladesh. Data was collected from 120 consumers. The survey questionnaire consisted of both close-ended and open-ended questions. Data on consumers' awareness and perception was collected through a mixture of dichotomous questions, importance questions, buying propensity questions and matrix questions. Data for the econometric analysis of the research was collected through open-ended format questions, such as questions about households' monthly income, monthly expenditure etc. Although the sample size for the study was 120 , it shrank to 70 for the econometric analysis because of missing values in 
8 Organic farming: An exploratory study based on evidence from Bangladesh

the respondents' answers.

\section{Methods of analysis}

The data collected in this research was used for two types of analysis: (1) To present statistics reflecting the consumers' perceptions and awareness about organic food products, and (2) To estimate a regression model testing the hypothesis stated in this research that income is a major constraint in consumers' demand for organic rice. The regression model was estimated using STATA, and included variables depicting consumers' demand for organic rice, price of organic and inorganic rice, environmental awareness, health consciousness, quality satisfaction, family size and household income. Environmental awareness, health consciousness, quality satisfaction etc. are factors that could potentially affect consumers' demand for organic food products (Zanoli \& Naspetti, 2002; Hughner, McDonagh, Prothero, Shultz, \& Stanton, 2007). The data representing consumers' quantity demanded of organic rice, and price of organic and inorganic rice, involved comparatively complex cleaning and calculations for use in the regression analysis. On the other hand, the data of the other variables, such as household income, health consciousness, environmental awareness, family size, didn't require such intricate data cleaning for the regression analysis. The data calculation methods are as follow:

(1) Consumers' demand for organic rice:

Variable: Consumers' average organic rice quantity demand

Formula: $\overline{\mathrm{x}}=\frac{\sum \mathrm{X}}{\mathrm{n}}$

Here, $\mathrm{x}^{-}=$Average quantity demanded

$\mathrm{X}=\mathrm{Quantity}$ demanded of organic rice/ inorganic rice by each consumer

$\mathrm{n}=$ Number of observations

(2) Price of organic and inorganic rice:

Variables: Average weighted price of organic rice/inorganic rice

Formula: $\tilde{\mathrm{P}_{\mathrm{W}}}=\mathrm{W} \times \tilde{\mathrm{P}}$

Here, $\tilde{\mathrm{P}_{\mathrm{w}}}=$ Weighted average price

$\mathrm{W}=$ Weight $[$ Weight= particular amount of quantity demanded (either of organic rice or inorganic 
9 Organic farming: An exploratory study based on evidence from Bangladesh

rice) at a particular price $\div$ total quantity demanded (of both organic rice and inorganic rice) by the consumer at that price]

$\tilde{\mathrm{P}}=$ Consecutive price

Econometric Model

The econometric model is based on a multiple variable regression equation (OLS method).

In (Average quantity demanded of organic rice by consumer) $=\alpha+\beta_{1} \ln$ (Household Income of consumer $)+\beta_{2} \ln$ (Average quantity demanded of inorganic rice by consumer) $+\beta_{3}$ In (Average weighted price of organic rice) $+\beta_{4} \ln$ (Average weighted price of inorganic rice) $+\beta_{5}$ Environmental awareness dummy variable $+\beta_{6}$ Education level dummy variable $+\beta_{7}$ Health consciousness dummy variable $+\beta_{8} \ln$ (Family size) $+\beta_{9}$ Quality Satisfaction dummy variable + error

The variables in the model follow from the basic 'Law of Demand' of Economics, which states that demand for a good is inversely related to its price. The other factors affecting demand include income, consumer's preference etc. The variables 'Environmental awareness', 'Health consciousness', 'Quality satisfaction' have been included in the model, in the form of dummy variables, based on the assumption that these influence consumer's preference towards organic foods.

The econometric model was tested on the basis of 'goodness of fit' by the R square method, and the significance of the effects of the independent variables on the dependent variable was calculated using the $\mathrm{P}$ value test. The VIF tolerance method was used to test the existence of multicollinearity; the Breusch-Pagan test was used to test the existence of heteroscedasticity, and the Ramsey RESET (Regression Specific Error Test) was used to test specification bias in the model. 
10 Organic farming: An exploratory study based on evidence from Bangladesh

\section{Findings and Discussion}

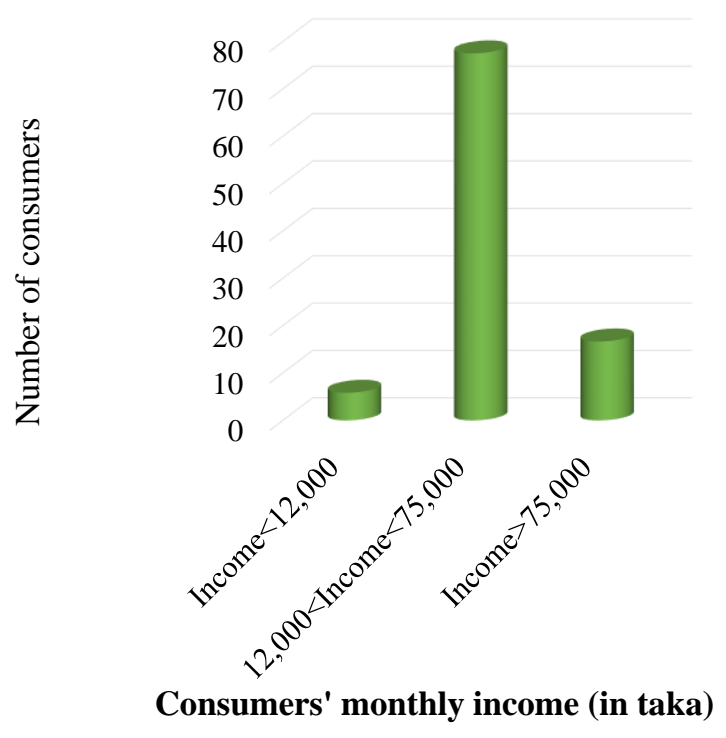

Figure no.1: Monthly income (in taka) of the respondents $(n=120)$

The monthly income of the consumers is an indication of their social status. According to the respondents' income distribution, three income levels have been identified- (1) Monthly income less than 12,000 taka, (2) Monthly income between 12,000 taka and 75,000 taka and (3) Monthly income above 75,000 taka. Among the respondents, $77.5 \%$ fell under the middle income group $(12,000$ taka<Monthly income<75,000 taka), which indicates a strong middle-income bias in the data. This bias indicates that the two grocery stores where the survey was conducted are reasonably affordable places for lower-middle class, middle class people, as well as definitely for higher middle class and upper class people, to shop for daily groceries, such as rice. Usually, middle class, upper class and lower class categories are classified based on income status and living conditions of consumers. The middle income bias could be helpful in proving the hypothesis that income constraint is a major barrier to consumers' purchasing organic rice, because it would be able to identify whether lack of awareness about organic products or income constraint is the stronger factor affecting consumers' demand for organic rice. If there had been either a high-income bias or low income bias in the data, then this dimension might have been harder to capture; because consumers with higher levels of income would be less likely to have the income constraint factor, and consumers with lower income levels would be less likely to be aware of the benefits of organic food products. On the other hand, assuming that the hypothesis of this research is true, and income is a major constraint in consumers' demand for organic rice, the middle income bias could mean that the perceptions of many consumers' with higher income levels and willingness to purchase organic food would be missed out. 
11 Organic farming: An exploratory study based on evidence from Bangladesh

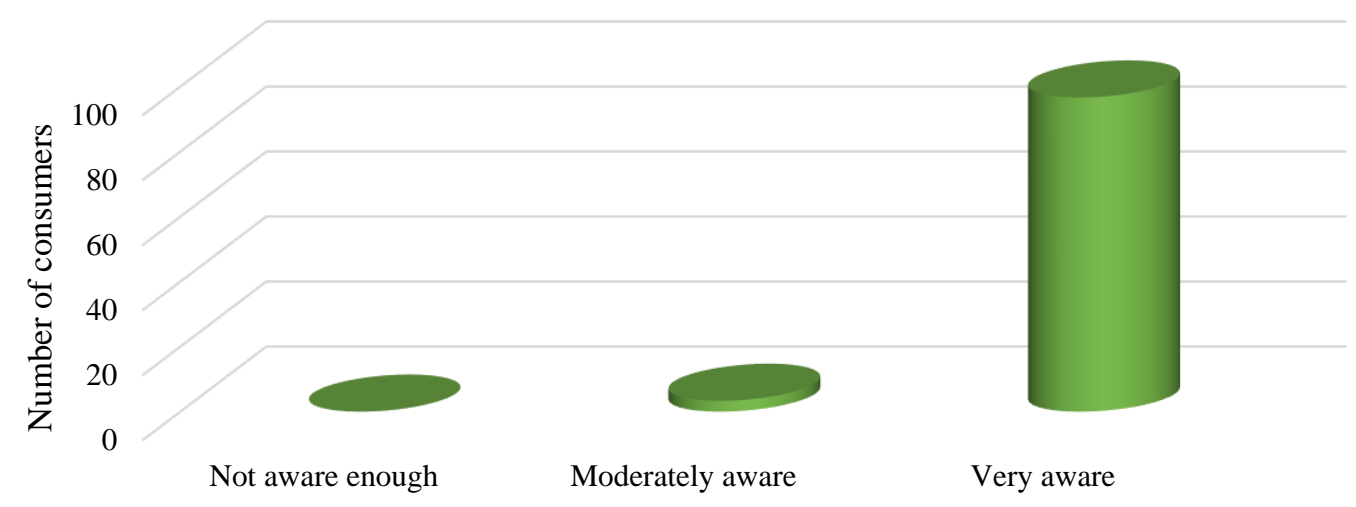

How environmentally aware are the respondents?

Figure no.2: Environmental awareness of the consumers $(n=120)$

Figure no. 2 shows that $3.33 \%$ of the respondents are moderately aware about what harms the environment and how to preserve the environment; and $96.67 \%$ of the respondents are very aware. In this case, environmental awareness was measured by asking the respondents questions (framed in a 'Likert scale' structure) about the environment, pollution, green farming etc. and the respondents' answers to the questions were categorized into high, medium, low awareness groups. Most of the respondents stated that they knew about organic food, the threats of inorganic food to the environment, and the environmental benefits of organic farming. A majority of the respondents being identified as very aware of environmental issues confirms that there is little and close to no lack of awareness in these respondents about the environmental benefits of organic food production.

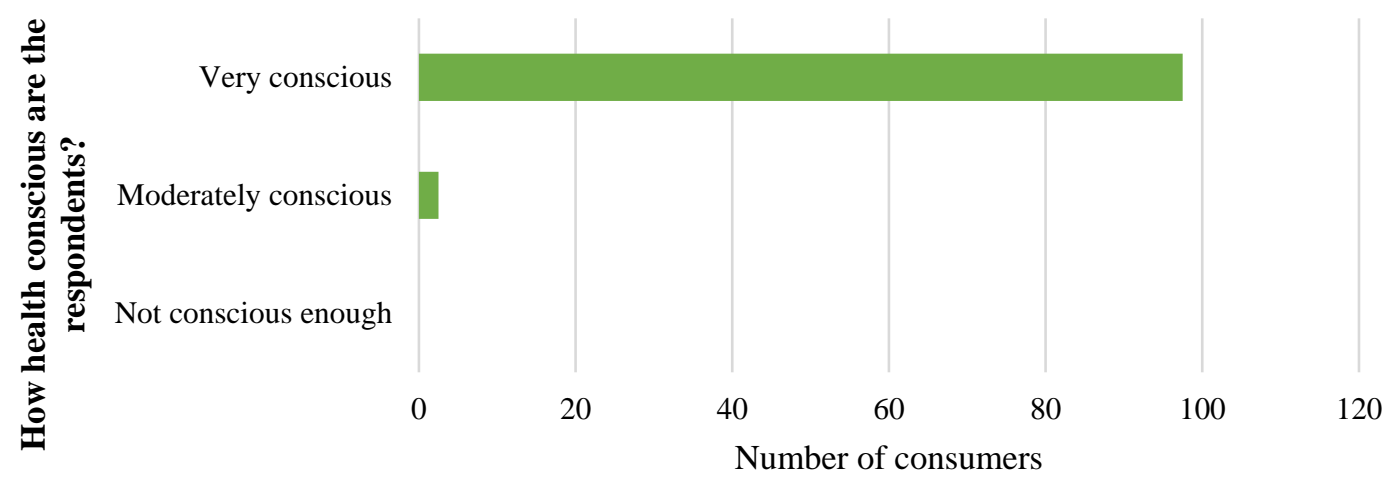

Figure no.3: Health consciousness of consumers' $(n=120)$

Figure no. 3 shows that $2.5 \%$ of the respondents are moderately conscious of what affects their health positively and negatively; and most of the respondents $(97.5 \%)$ are very conscious of their health. Health consciousness was measured by asking the respondents questions (framed in a 'Likert scale' structure) about smoking, healthy dieting, exercise etc. and especially about their views on what types of food are harmful for their health. The respondents were specifically probed 
12 Organic farming: An exploratory study based on evidence from Bangladesh

about their concern about how inorganic food could be affecting their health. The respondents' answers were categorized into three levels of consciousness. Most of the respondents being conscious about their health could be an indication that they would be willing to purchase organic foods for the betterment of their health if they could afford it. Thus, this could be considered a signal that income constraint is affecting these consumers' decisions to purchase organic foods.

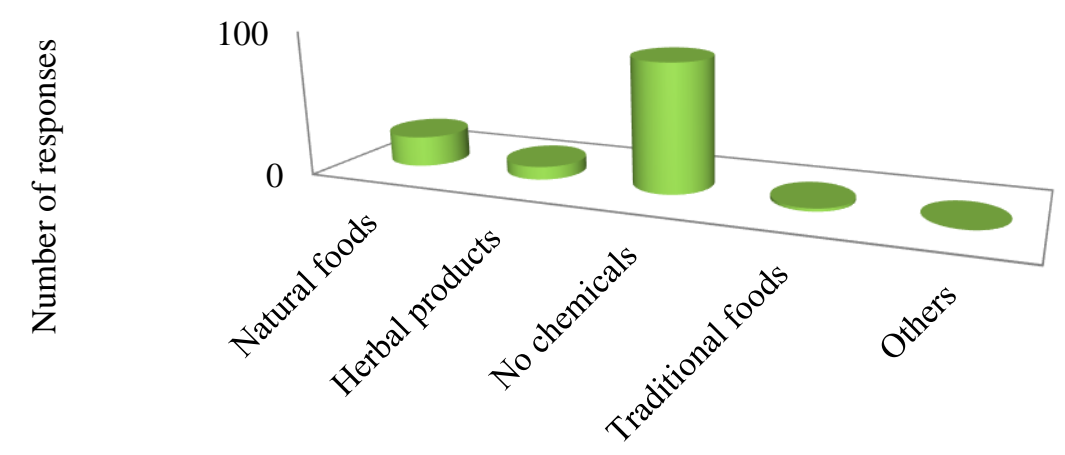

What do the consumers understand by the term 'organic food'?

Figure no.4: Consumers' understanding of the term 'organic food' $(n=120)$

Figure no. 4 shows that most consumers (88 out of 120) understand organic food to be products produced without chemical pesticide usage; while 21 out of 120 consumers perceive organic food to be natural food made with natural unprocessed ingredients. This portrays that although most respondents are aware of the basic concept of organic foods, perhaps their understanding of the term could be clearer, especially in terms of the methods used in producing the organic food products.

Table 1: Cross-tabulation of consumers' income status and their willingness to pay more for certified organic foods $(\mathbf{n}=\mathbf{1 2 0})$

\begin{tabular}{|c|c|c|c|c|c|}
\hline & & \multicolumn{3}{|c|}{ Income status of the consumers } & \\
\hline & & $\begin{array}{c}\text { Below } \\
12,000 \text { taka }\end{array}$ & $\begin{array}{c}(12,000 \text { to } \\
75,000) \text { taka }\end{array}$ & $\begin{array}{c}\text { Above } 75,000 \\
\text { taka }\end{array}$ & Total \\
\hline $\begin{array}{c}\text { Willingness to } \\
\text { pay more for } \\
\begin{array}{c}\text { certified organic } \\
\text { foods }\end{array}\end{array}$ & $\begin{array}{c}\text { Not } \\
\text { willing }\end{array}$ & 3 & 0 & 0 & $\begin{array}{c}3 \text { out of } 120 \\
\text { respondents }\end{array}$ \\
\cline { 2 - 7 } & Willing & 4 & 93 & 20 & $\begin{array}{c}117 \\
\text { Out of } 120 \\
\text { respondents }\end{array}$ \\
\hline & Total & 7 & 93 & 20 & 120 \\
\hline
\end{tabular}

Table 1 indicates that $97.5 \%$ of the respondents (117 out of 120 respondents) are willing to 
13 Organic farming: An exploratory study based on evidence from Bangladesh

purchase certified organic foods even if it costs them more than purchasing the alternate inorganic versions of the products. The three consumers who responded that they would not be willing to purchase organic food items at higher prices were found to be in the lower income group (monthly income $<12,000$ taka). This is a clear indication that income constraint negatively affects the consumer's willingness to purchase organic food items.

Table 2: Cross tabulation between consumers' purchasing status of organic items with monthly food expenses $(n=120)$

\begin{tabular}{|c|c|c|c|c|c|}
\hline & \multicolumn{4}{|c|}{ Consumers' organic food purchasing status } & \\
\hline Monthly food expenses(taka) & Regular & Frequent & Seldom & Never purchase & Total \\
\hline Below 10,000 & 0 & 0 & 7 & 0 & 7 \\
\hline $10,000-15,000$ & 10 & 12 & 8 & 0 & 30 \\
\hline $16,000-20,000$ & 27 & 33 & 3 & 0 & 63 \\
\hline $21,000-25,000$ & 5 & 5 & 0 & 0 & 10 \\
\hline $26,000-30,000$ & 6 & 0 & 0 & 0 & 6 \\
\hline Above 30,000 & 4 & 0 & 0 & 0 & 4 \\
\hline Total & 52 & 50 & 18 & 0 & 120 \\
\hline
\end{tabular}

Table 2 shows that $77.5 \%$ (93 of the 120) of the respondents spend between 10,000 taka to 20,000 taka per month on food products, while $16.67 \%$ of the respondents (20 out of 120 ) spend more than 20,000 taka per month on food, and only 5.83\% (7 out of 120) of the respondents' monthly food expenditure is below 10,000 taka. Although these figures seem coherent with the income distributions of the three income level groups in this study, monthly food expenditure does not depend on income alone, but rather also depends on 'how many mouths to feed?', or simply the family size of the respondents. So, respondents' monthly food expenditure cannot be linked with the income groups alone without data of how many people each of the respondents' buy food for. The data in table 2 shows some important patterns nonetheless- (1) Out of the 20 respondents whose monthly food expenditure is comparatively quite high (greater than 20,000 taka per month), 15 respondents' confirmed that they purchase organic food products instead of inorganic ones regularly; and (2) 52 of the 120 consumers (43.3\%) regularly purchase organic items; 50 of the 120 respondents $(41.7 \%)$ frequently purchase organic food products, and 18 of the 120 respondents $(15 \%)$ seldom purchase organic items. In this data, there seems to be a positive relationship between monthly food expenditure and purchasing organic food products. Although it cannot be claimed with certainty that high monthly food expenditure indicates higher income levels, the data from table 2 does indicate that quite a large number of respondents have the willingness to purchase organic foods in their regular grocery shopping. 
14 Organic farming: An exploratory study based on evidence from Bangladesh

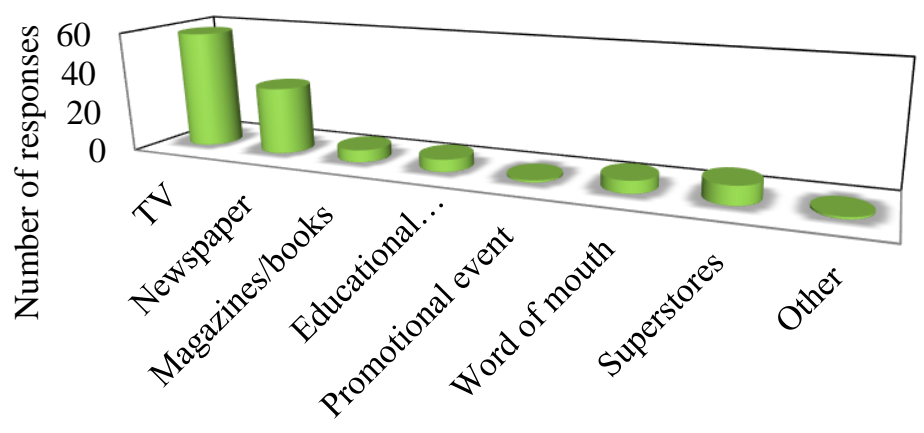

How did the consumers' know and learn about organic food products?

Figure no. 5: Consumers' source of information in learning about organic foods $(n=120)$

Figure no. 5 shows that $48.3 \%$ of the respondents' (58 out of 120 of the respondents) came to know about organic food products from advertises on television and from TV programs promoting organic food production (health shows, talk shows on health and environment etc.); and 27.5\% (33 out of 120) of the respondents learnt about organic food items from newspaper reviews, articles and advertises. Respondents who said that they had learnt about organic food from TV programs were asked to mention specific TV programs and channels they had watched in learning about organic food; and all of the respondents' answers revealed that the shows had been on international channels rather than on national TV channels. It cannot be claimed with certainty that organic food promotion on national TV platforms are scarce, but the different medias that can be used in spreading awareness about organic foods can be researched more to reach a wider audience in both rural and urban areas in Bangladesh.

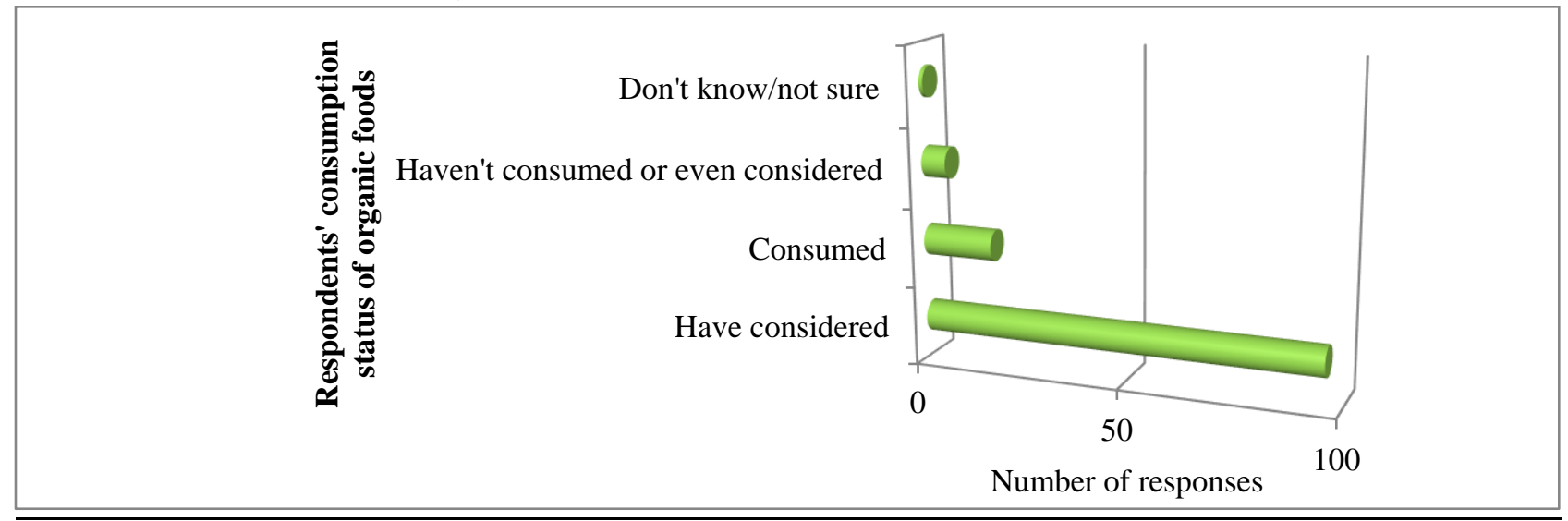

Figure no.6: Whether the consumers ever consumed or considered consumingorganicfood(n=120)

Figure no. 6 shows that $80 \%$ (96 out of 120) of the respondents have considered consuming organic foods but haven't consumed (all 96 of the respondents indicated the reason behind this to be the high price of the organic products and the lack of affordability); while only $14.17 \%$ (17 out of 120) of the respondents have actually purchased and consumed organic foods. 
15 Organic farming: An exploratory study based on evidence from Bangladesh

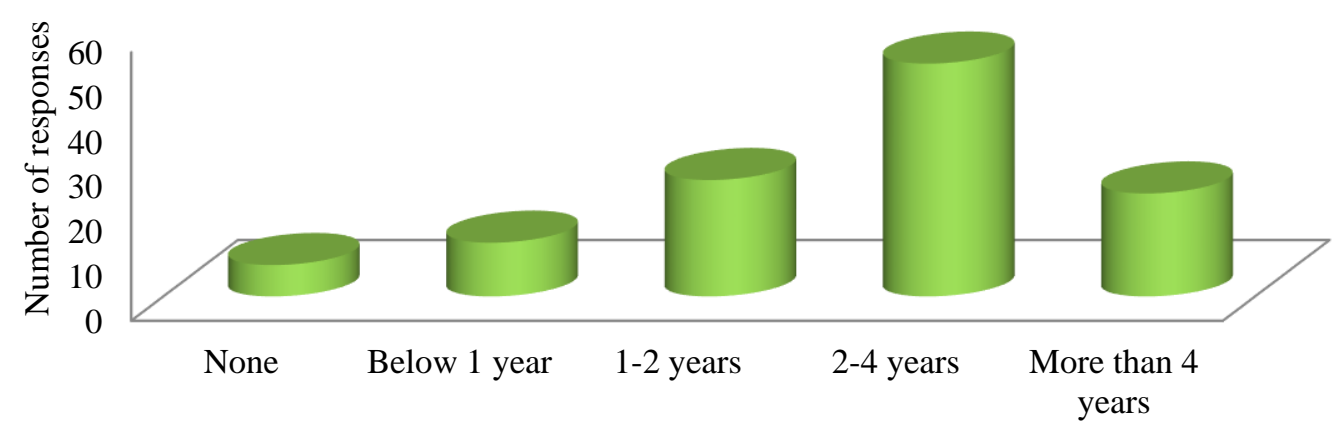

How long have the consumers been purchasing organic food products?

Figure no.7: Consumers' time period of having been aware about organic products and having started purchasing organic food products from time to time $(n=120)$

Figure no. 7 shows that only 7 of the 120 respondents $(5.83 \%)$ have not purchased any organic food items yet; 38 out of the 120 respondents (31.67\%) have been purchasing for at least a year; and 75 out of the 120 respondents $(62.5 \%)$ have been purchasing organic food products from time to time for at least two years and more. The respondents who had been purchasing organic foods for at least a year or for more than one year were asked why they had made the conscious shift towards purchasing organic foods, and $97 \%$ of them responded that it was because they had realized the health benefits of the organic products and had made the shift only when they could afford to buy the organic products.

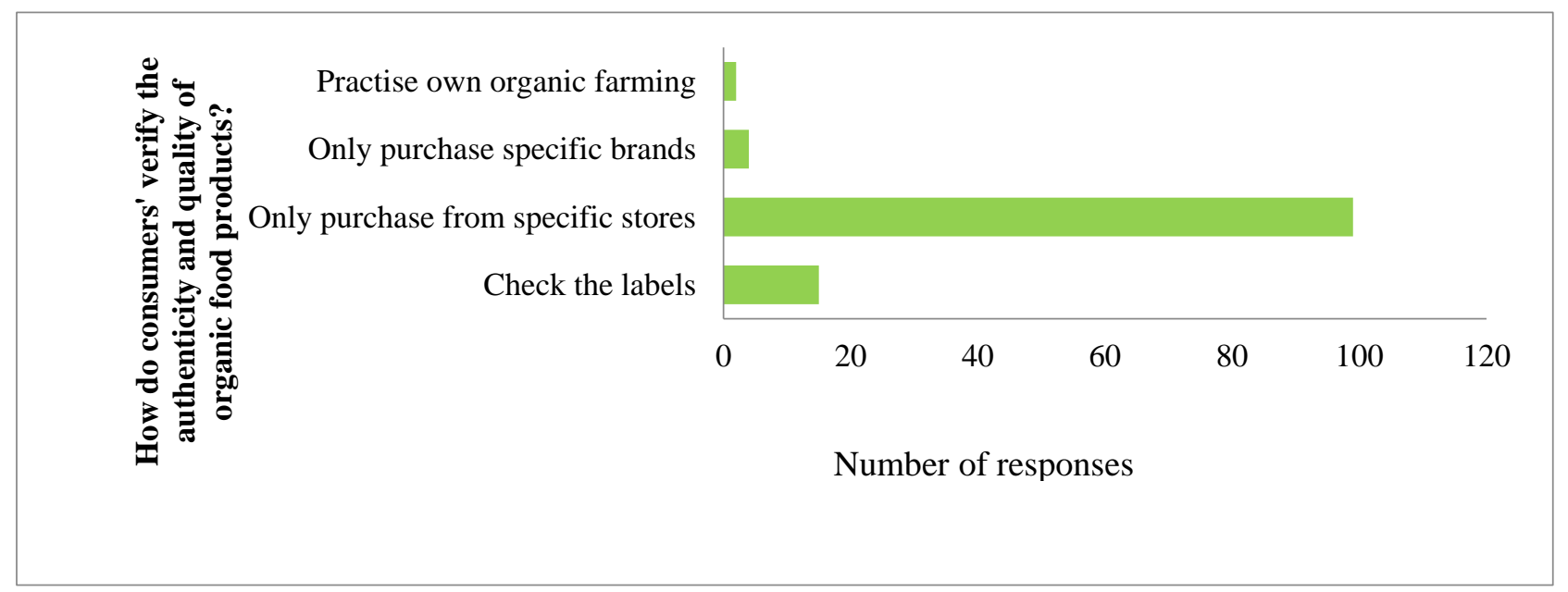

Figure no.8: Consumers' organic food products verifying system $(n=120)$

Figure no. 8 shows that most of the respondents (93 out of 120 respondents) prefer to buy organic food products from specific stores that they are familiar with and trust; while many consumers (15 out of 120 respondents) opt for checking the labels of the food products and the company name to verify the quality and authenticity of the organic food products. 
16 Organic farming: An exploratory study based on evidence from Bangladesh

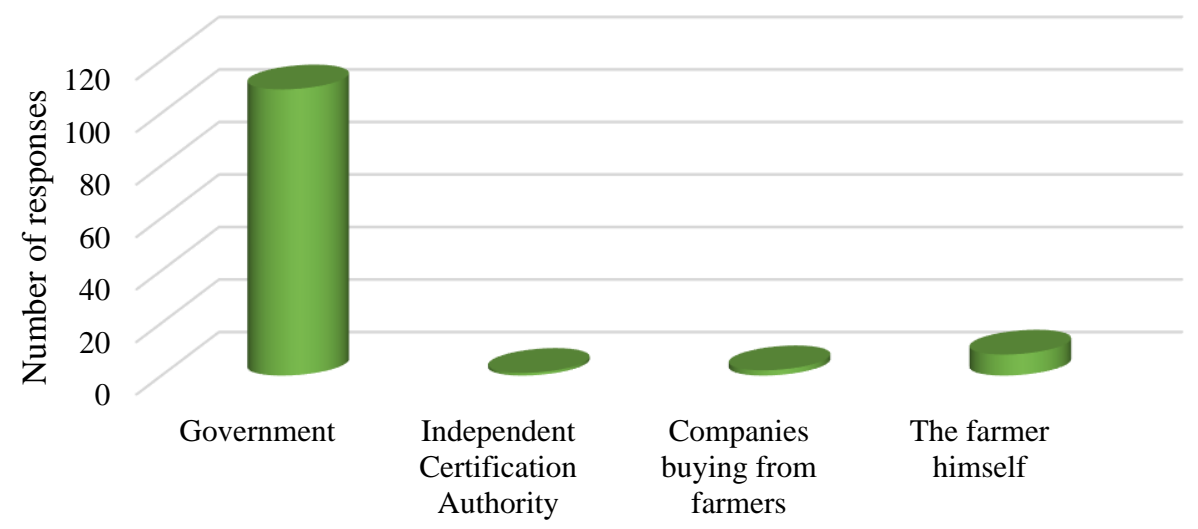

Who do the consumers think should be responsible for ensuring the quality and authenticity of organic food products?

Figure no. 9: Consumers' perception about responsibility of verification

Figure no.9 shows that $90.83 \%$ of the respondents (109 out of 120 respondents) think that the government should be responsible for verifying the quality and authenticity of the organic food products. Consumers' perceptions on issues like such verifications are very important for the growth of the organic food market, because these are the issues that the authorities and suppliers would have to take into account to maximize their business opportunities, supplies and profits in the organic food market.

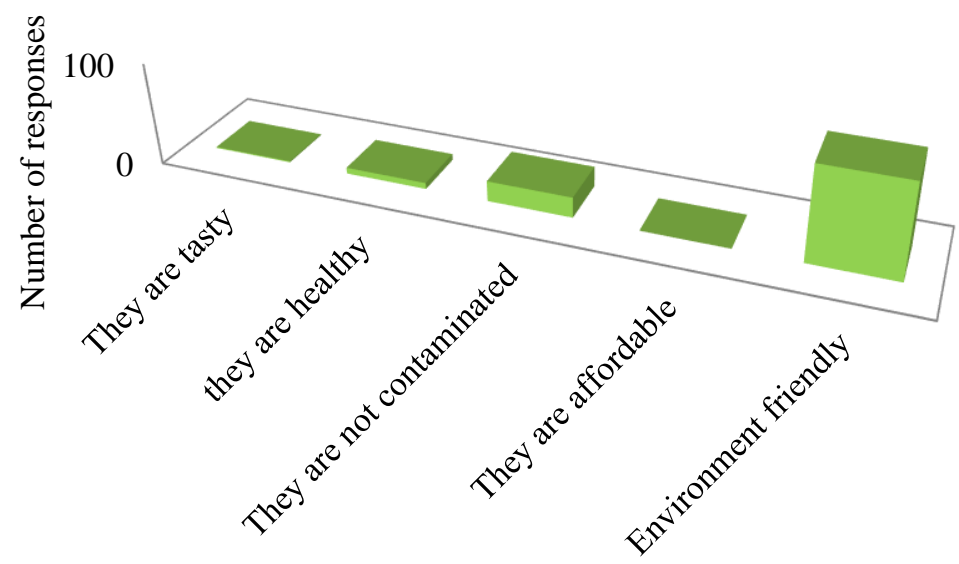

Reasons behind consuming organic food products

Figure no.10: Consumers reasons for purchasing and consuming organic food products $(\mathbf{n}=\mathbf{1 2 0})$

Figure no. 10 shows that $77.5 \%$ of the respondents (93 out of 120) have purchased and consumed organic food products because of the products being environmentally friendly, and this indicates that the respondents of the survey in this research are quite concerned about conserving the 
17 Organic farming: An exploratory study based on evidence from Bangladesh

environment. So, there seems to be little to no lack of awareness among the respondents about the environmental benefits of organic food products, and this could rule out lack of awareness as a reason behind these consumers' not purchasing organic food products.

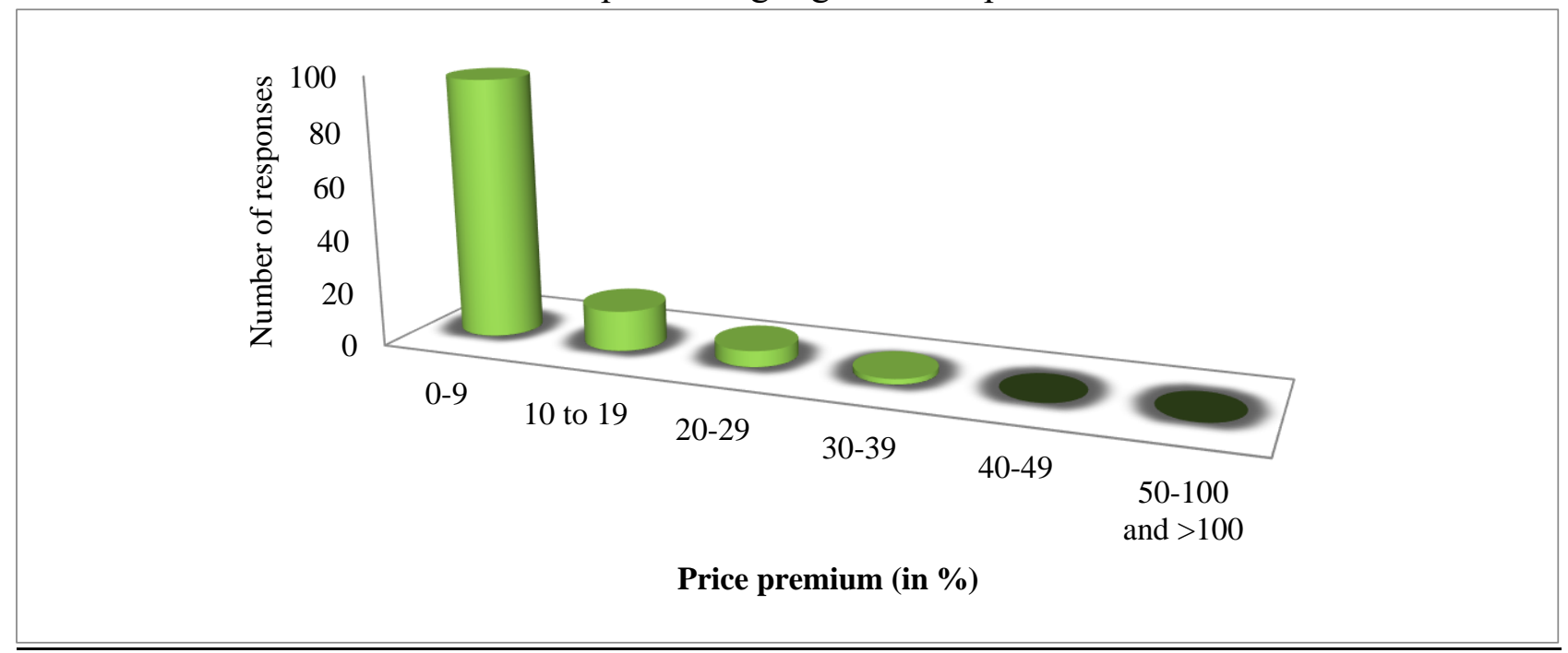

Figure no. 11: Premium price that consumers would be willing to pay for organic rice $(n=120)$

Figure no. 11 shows that $80.83 \%$ of the respondents (97 out of 120) would be willing to pay $0-9 \%$ premium price, meaning that they would be willing to pay a maximum of $9 \%$ more than the price of inorganic rice to purchase organic rice. Moreover, $19.17 \%$ of the respondents (23 out of 120) said that they would be willing to pay over $9 \%$ premium price, and even up to $39 \%$ in case of some of the respondents for organic rice instead of inorganic rice. The respondents who were willing to pay $20 \%$ or over $20 \%$ price premium were in the high income status groups (Monthly income> 75,000 taka).

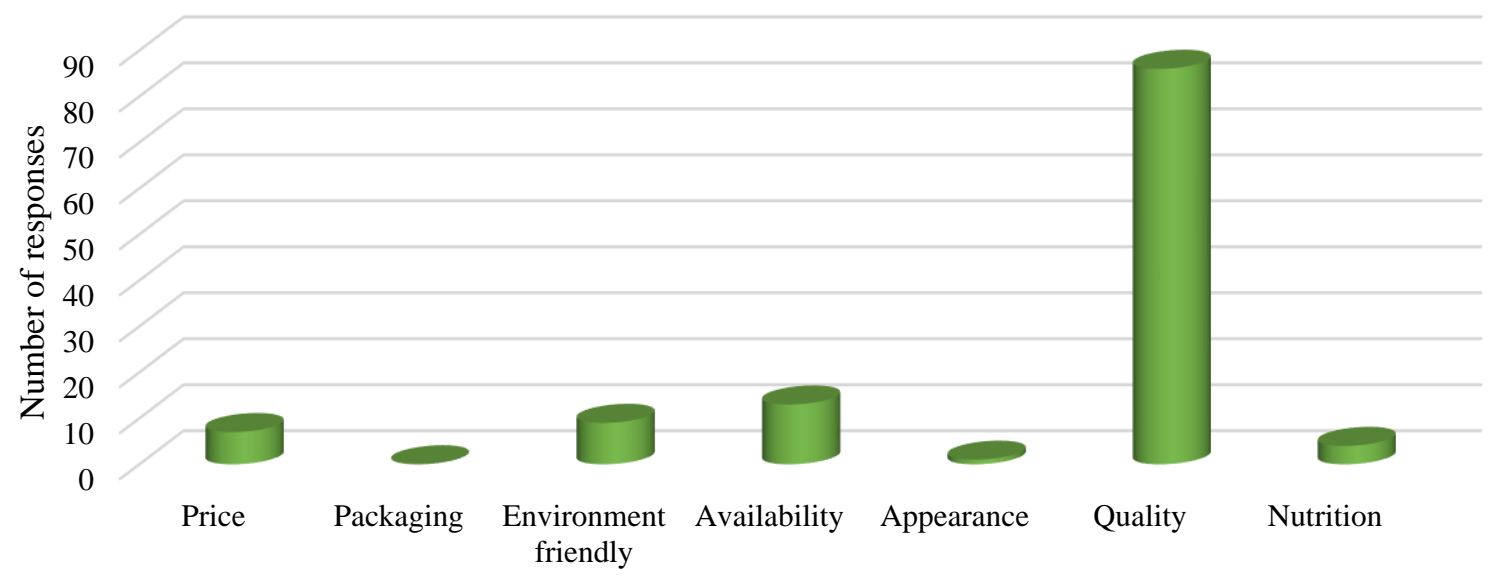

What characteristics persuade consumers to purchase more organic food products?

Figure no.12: Characteristics that persuade consumers to buy more green products (n=120)

Figure no. 12 shows that the quality of the organic food products is the most popular characteristic 
that attracts the respondents to purchase organic food products. Around $71.67 \%$ of the respondents stated quality to be the most persuading characteristic that pulls them towards consuming green products. This is a signal to authorities of organic food supply chains to ensure the quality of organic products in order to meet the demand criteria of the consumers of the organic food market.

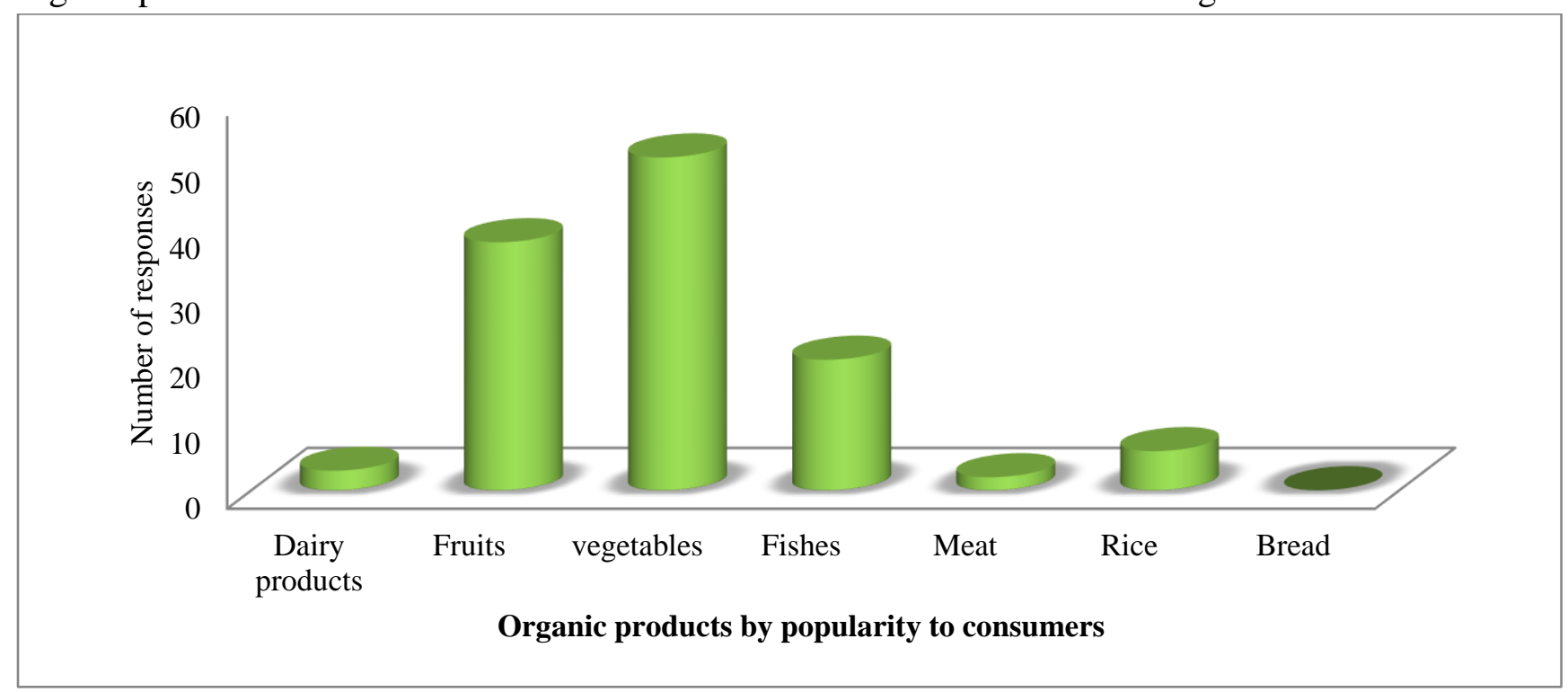

Figure no.13: Ranking organic food products by popularity among consumers $(n=120)$

Figure no. 13 shows that vegetables are the most popular (51 out of 120 respondents) organic food followed consecutively by fruits (38 out of 120 respondents); and fish (20 out of 120 respondents). This could be a reflection of the general suspicion, which has also gained widespread media coverage, about the extensive usage of harmful formalin, pesticides in fresh fruits, vegetables, and fish in Bangladesh. Food Adulteration has been a topic covered by the media extensively, which might have had an influence on consumers opting to buy organic fruits, vegetables, fish etc.

Table no.3: Summary of the consumers' perception regarding available organic foods in Dhaka City in 2012(n = 120)

\begin{tabular}{|l|l|l|l|}
\hline Statement & Agreed & Partially agreed & Not agreed \\
\hline $\begin{array}{l}\text { Available organic foods in Bangladesh are really } \\
\text { organic }\end{array}$ & $\begin{array}{l}42 \\
(35 \%)\end{array}$ & $\begin{array}{l}64 \\
(53.33 \%)\end{array}$ & $\begin{array}{l}14 \\
(11.76 \%)\end{array}$ \\
\hline Quality of the available organic foods is satisfactory & $\begin{array}{l}11 \\
(9.17 \%)\end{array}$ & $\begin{array}{l}104 \\
(86.7 \%)\end{array}$ & $\begin{array}{l}5 \\
(4.17 \%)\end{array}$ \\
\hline Price of organic foods is very high & $\begin{array}{l}112 \\
(93.33 \%)\end{array}$ & $\begin{array}{l}8 \\
(6.67 \%)\end{array}$ & $\begin{array}{l}0 \\
(0 \%)\end{array}$ \\
\hline Supply of organic food items in the market is sufficient. & $\begin{array}{l}16 \\
(0 \%)\end{array}$ & $\begin{array}{l}104 \\
(13.33 \%)\end{array}$ & $\begin{array}{l}23 \\
(86.7 \%)\end{array}$ \\
\hline Number of organic shops is sufficient in the city & $\begin{array}{l}93.17 \%) \\
(0 \%)\end{array}$ & $(80.83 \%)$ \\
\hline
\end{tabular}


19 Organic farming: An exploratory study based on evidence from Bangladesh

\begin{tabular}{|l|l|l|l|}
\hline $\begin{array}{l}\text { Organic foods should be certified by the certifying } \\
\text { authorities }\end{array}$ & $\begin{array}{l}100 \\
(83.3 \%)\end{array}$ & $\begin{array}{l}20 \\
(16.7 \%)\end{array}$ & $\begin{array}{l}0 \\
(0 \%)\end{array}$ \\
\hline All types of food crops should be cultivated organically & $\begin{array}{l}120 \\
(100 \%)\end{array}$ & $\begin{array}{l}0 \\
(0 \%)\end{array}$ & $\begin{array}{l}0 \\
(0 \%)\end{array}$ \\
\hline Organic foods have less pesticides/chemicals & $\begin{array}{l}118 \\
(98.3 \%)\end{array}$ & $\begin{array}{l}2 \\
(1.7 \%)\end{array}$ & $\begin{array}{l}0 \\
(0 \%)\end{array}$ \\
\hline Organic farming help protect environment and ecology & $\begin{array}{l}120 \\
(100 \%)\end{array}$ & $\begin{array}{l}0 \\
(0 \%)\end{array}$ & $\begin{array}{l}0 \\
(0 \%)\end{array}$ \\
\hline Organic farming is as sustainable as inorganic farming & $\begin{array}{l}119 \\
(99.17 \%)\end{array}$ & $\begin{array}{l}1 \\
(0.83 \%)\end{array}$ & $\begin{array}{l}0 \\
(0 \%)\end{array}$ \\
\hline
\end{tabular}

Table no.4: Problems faced by the consumers of organic products in $2012(\mathrm{n}=120)$

\begin{tabular}{|l|l|}
\hline Problems & No. of consumers \\
\hline Insufficient supply of organic produce & $44(36.7 \%)$ \\
\hline Organic foods are available in a limited number of shops & $3(2.5 \%)$ \\
\hline Lack of trust of producers and sales personnel & $23(19.17 \%)$ \\
\hline High price of organic produce & $48(40 \%)$ \\
\hline Others & $0(0 \%)$ \\
\hline
\end{tabular}

Table no. 4 shows that regarding the consumption of organic food in Bangladesh, $40 \%$ consumers' face the problem of high price; while $36.7 \%$ face the problem of insufficient supply. High price being perceived as a problem could be linked to the income constraint of consumers, indicating that income constraint could be a strong determinant in consumers' organic food purchasing.

Findings from the Regression Analysis

Table no.4: Regression Results

\begin{tabular}{|c|c|c|c|c|}
\hline Source & SS & Df & MS & Number of observations $=70$ \\
\hline Model & 20.376 & 9 & 2.264 & $\mathrm{~F}(9,48)=13.39$ \\
\hline Residual & 8.118 & 48 & 48.169 & Probability $>\mathrm{F}=0.00$ \\
\hline Total & 28.495 & 57 & 57.499 & R-squared $=0.72$ \\
\cline { 4 - 5 } & & & & Adjusted R-squared $=0.66$ \\
\cline { 4 - 5 } & & & & Root MSE $=0.41$ \\
\hline
\end{tabular}

\begin{tabular}{|c|c|c|c|c|}
\hline Organic rice demand $(\ln )$ & Coefficient & Standard Error & $\mathrm{t}$ value & P value \\
\hline Consumer's income $(\ln )$ & 0.618 & 0.118 & 5.23 & $0.000^{*}$ \\
\hline Inorganic rice demand $(\ln )$ & 0.314 & 0.104 & 3.02 & $0.004^{*}$ \\
\hline Organic rice price $(\ln )$ & 1.858 & 0.877 & 2.12 & $0.039^{*}$ \\
\hline Inorganic rice price $(\ln )$ & 1.154 & 0.826 & 1.40 & 0.169 \\
\hline Family size $(\ln )$ & 0.772 & 0.513 & 1.51 & 0.139 \\
\hline
\end{tabular}


20 Organic farming: An exploratory study based on evidence from Bangladesh

\begin{tabular}{|c|c|c|c|c|}
\hline Environmental awareness (dummy) & 0.528 & 0.396 & 1.33 & 0.189 \\
\hline Education level(dummy) & -0.488 & 0.409 & -1.19 & 0.238 \\
\hline Health consciousness(dummy) & 0.3645 & 0.394 & 0.93 & 0.359 \\
\hline Quality satisfaction (dummy) & 0.492 & 0.273 & 1.80 & $0.078^{* *}$ \\
\hline Constant & -18.33688 & 2.989109 & -6.13 & 0.000 \\
\hline
\end{tabular}

*Statistically significant at 5\% significance level

**Statistically significant at $10 \%$ significance level

\section{Discussion of the regression results}

(1) The regression results show that the average quantity demanded of organic rice increases by approximately $0.62 \%$ when the consumer's income increases by $1 \%$.

(2) On the other hand, environmentalawarenessdummy $=1$ indicates that the consumers are environmentally aware. The results show that the average quantity demanded of organic rice by aware consumers is $53 \%$ greater than that of unaware consumers'.

(3) Similarly, healthconsciousnessdummy $=1$ indicates that the consumers are health conscious; while the results show that conscious consumers' average quantity demanded of organic rice is around $36 \%$ greater than that of unconscious consumers'.

(4) The regression results show that the 'average quantity demanded of organic rice' by consumers is largely affected by the consumer's income, besides the prices of organic rice and the substitute inorganic rice. Environmental awareness and health awareness don't impact the change in consumers' demand as much as income does.

(5) Most importantly, the coefficients for 'Environmental awareness' and 'Health consciousness' are not statistically significant. In this regression model, the coefficients of 'consumers' income', 'average quantity demanded of inorganic rice', 'average weighted price of organic rice' are statistically significant at the 5\% significance level and the coefficient of 'Quality Satisfaction' is significant at the $10 \%$ significance level. The regression results provide proof that income level and price are two of the most important factors that influence consumers' average quantity demanded of organic rice in this regression model.

(6) The results can be better perceived from the graphical analysis: 
21 Organic farming: An exploratory study based on evidence from Bangladesh

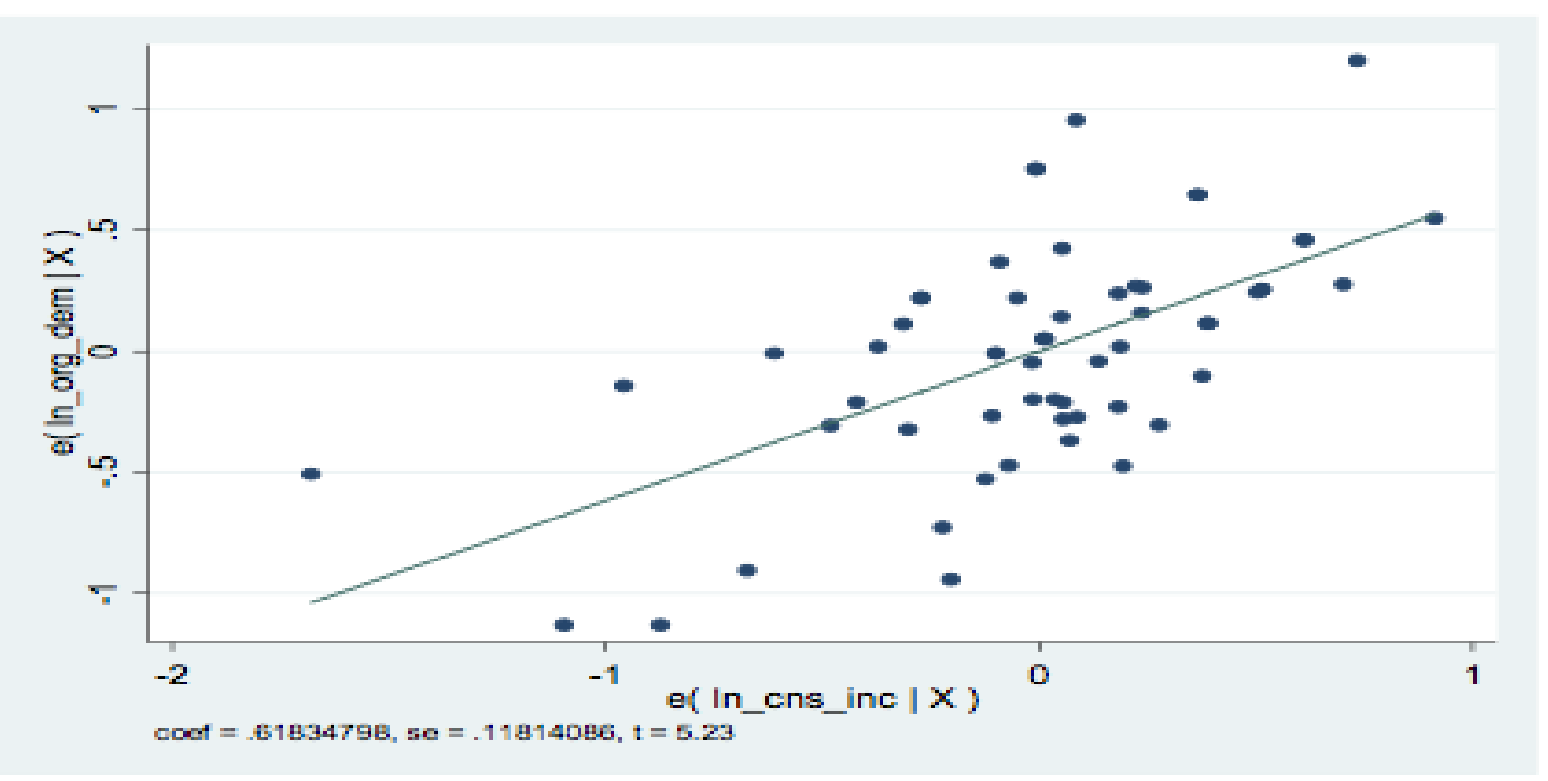

\section{Graph no.1: Relationship between average quantities demanded of organic rice and income of consumer.}

The upward-sloping line in graph no. 1 confirms that there is a positive relationship between the variables 'average quantity demanded of organic rice' and 'income'. The important issue here is whether this relationship is stronger in magnitude than the relationships of average quantity demanded of organic rice with other factors.
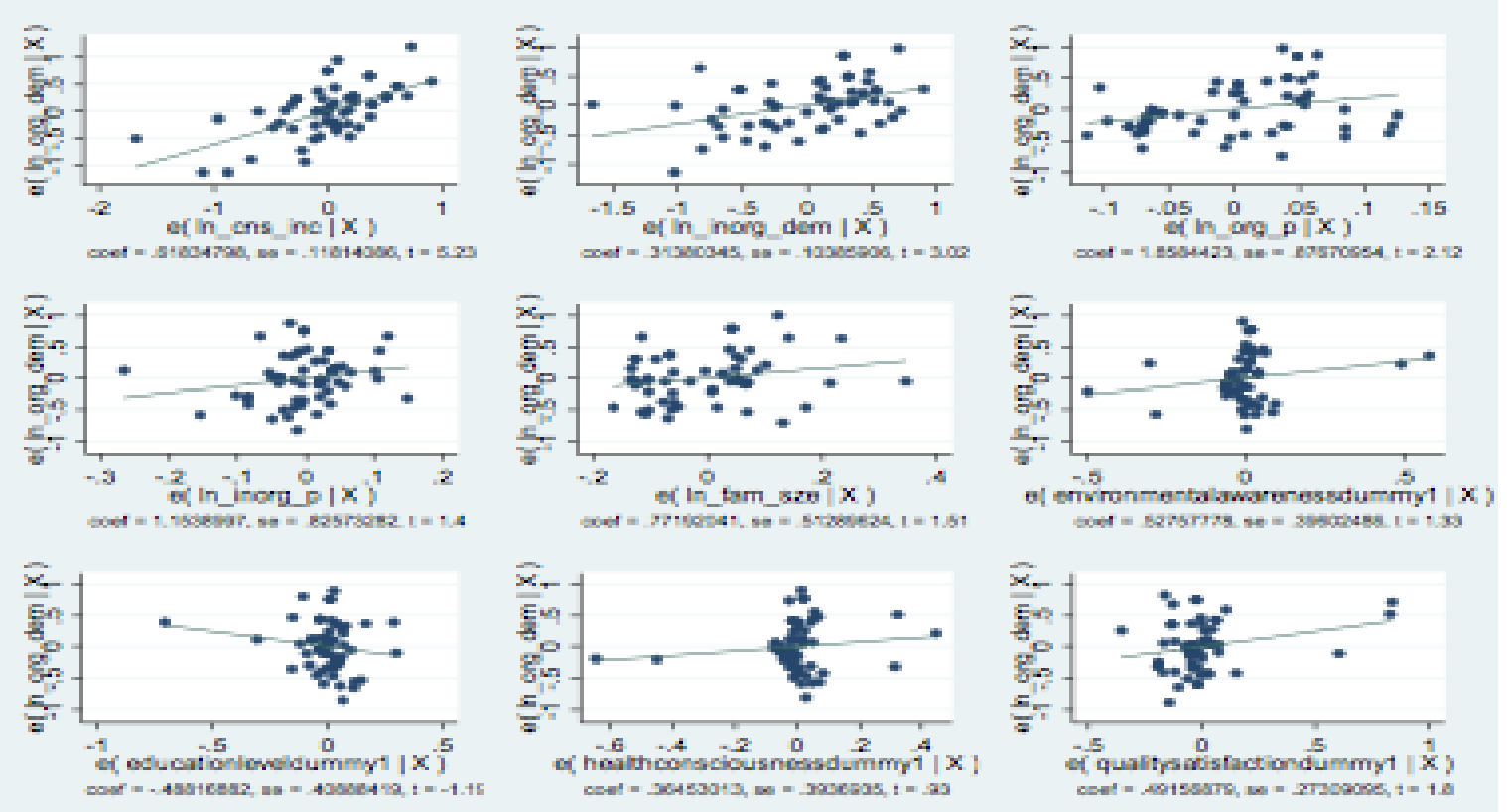

Graph no.2: Comparison of slopes

This graph shows how the consumer's income is the factor that affects the average quantity demanded of organic rice the most (indicated by the steepest slope among all the graphs: the graph 
22 Organic farming: An exploratory study based on evidence from Bangladesh

\section{at the top left corner).}

The steeper the slope, the greater the change in average quantity demanded of organic rice due to a change in the corresponding independent variable. Considering only the variables that are statistically significant- the slopes of the graphs above indicate that consumer's income is the factor that affects the average quantity demanded of organic rice the most, which is indicated by the steepest slope among all the graphs. Thus, consumer's income is the most influencing factor in determining the average quantity demanded of organic rice by the consumers.

(7) The results show that no matter how conscious consumers' become of the advantageous effects of organic rice on the environment and on their health- in the end, their demand and consumption is mainly controlled by the level of incomes they earn and the price of the organic products. Organic products are generally highly priced, and so the consumer's willingness to purchase organic products is mainly dependent on income.

(8) There is a positive relationship of 'average quantity demanded of organic rice' with each of the variables of consumer's income, average weighted price of organic rice, average weighted price of inorganic rice, average quantity demanded of inorganic rice, environmental awareness dummy variable, health consciousness dummy variable, quality satisfaction dummy variable; and the nature of these relationships are intuitive and logical.

(9) The positive relationship between 'average quantity demanded of organic rice' and 'average weighted price of organic rice' is interesting since it reflects the preferences of a consumer group that is so conscious about consuming organic rice that a rise in price does not reduce their demand for it, but rather raises it. Thus, organic rice in this analysis can be perceived as a 'Giffen good' according to the preference pattern of the consumers. The positive relationship between 'average quantity demanded of organic rice' and 'average quantity demanded of inorganic rice' indicates that these two goods are complementary goods in this case. Another interesting anomaly perceived in the results is the negative relationship between average quantity demanded of organic rice and the education level (dummy variable).

(10) The $\mathrm{R}^{\text {squard }}$ value shows that approximately $72 \%$ of the variation in average quantity demanded of organic rice is explained by the independent variables incorporated in the model.

(11) There is no multicollinearity [Annex no.4] in this model.

(12) There is no heteroscedasticity [Annex no.6] in this model.

(13) The Ramsey RESET test shows that the model has no specification bias [Annex no.5]. 
23 Organic farming: An exploratory study based on evidence from Bangladesh

\section{Justifying the feasibility of organic rice farming in Bangladesh}

The most common concern in purchasing organic foods is the cost. Organic foods typically cost more than their non-organic conventional versions. The main reason behind the higher prices is the more expensive farming techniques and natural inputs required for the production of organic crops. Economics laws state that supply of a product is linked with the demand for it; and the price of products also responds to the demand dynamics in the market (Whelan, Msefer, \& Chung, 2001). If we assume that the production and supply of organic rice is determined by the demand for it, then it makes sense why the organic crop market in Bangladesh is not expanding; because market size does influence supply/ production (Melitz \& Ottaviano, 2008). Following our core finding in this paper that consumers' demand for organic rice is mainly dependent on their income level, and since the income level of Bangladesh's mass people is in the lower-middle income stage on average- it can be assumed that most people would not consume organic rice in their daily lives, no matter how much they would like to. The results of this study indicate that environmental awareness and health consciousness are not as powerful determinants of consumers' demand for organic rice as income constraint. So, as long as the general average income level of the nation does not increase- the demand for and consumption of organic rice might not increase as much, despite people becoming more aware of environment and health issues. So, the findings of this research suggest that perhaps the organic rice market in Bangladesh is rather stagnant because the producers and sellers do not perceive enough demand for the market to cater to it; and the demand for organic products is low because of the comparatively lower general income level of consumers. Another notion could be that consumers' demand for and consumption of organic rice in Bangladesh does not increase because of the consumers' doubt about the authenticity and quality of the organic products. Thus quality satisfaction and authenticity are important factors too. Therefore, before pursuing organic farming as the main mass method of farming in Bangladesh, it is vital to assure that income no longer remains a constraint for consumers in purchasing the organic crops. Since this study is exploratory in nature, the findings of this study could be further explored, verified and analysed in further research.

\section{Policy Recommendations}

It is necessary to create policies that will provide incentives, such as subsidies, to farmers to follow more organic agricultural methods; and also policies that will increase public demand for chemical-free crops (Rasul \& Thapa, 2004). Moreover, campaigns to increase demand for organically produced crops would help to attract consumers towards ecological agro-products, and would thereby increase both the market prices of these products and farmers' willingness to adopt ecological farming methods. According to Rasul and Thapa (2004), "To the extent that the country can bear its cost, providing subsidies for eco-products could be both financially and socially justified, if the environmental benefits that accrue to society are taken into account". The findings 
24 Organic farming: An exploratory study based on evidence from Bangladesh

in this article lead to the advocacy of the following policies.

(1) Focus on income level development in Bangladesh, and initiate endeavours that fasten becoming a middle-income nation. Only when the economy improves and income-level increases can the organic crop market expand. It is vital that such income-level increasing projects keep track of the rich-poor gap and assure that the incomes of people from all economy levels improve in the process, and that not only the wealthy are benefitted.

(2) Ensure the quality and authenticity of organic products; and provide facilities to existing organic producers to be able to market their crops more easily and efficiently. The government should play the leading role here, and there could be consumer bodies/unions created to keep track of the process. It is also important to create 'certifying bodies' that would be qualified to verify the authenticity and quality of organic crop products, and would have the authority to label the products as 'Certified Organics'. The Canadian Organic Standards (Martin, 2009) states that 'Certified organic' refers to crops produced according to the organic standards set by and certified by certifying bodies.

(3) The switch from inorganic farming to organic farming should be studied and researched on a massive scale.

(4) Keeping the environment factor and health issue in mind, innovative solutions should be implemented to begin the switch from inorganic farming to organic farming as soon as possible.

(5) Training and knowledge-sharing opportunities should be provided to farmers to learn about organic farming; and also for them to learn about the harms of inorganic farming. The government can launch organic food production training programs and integrated pest management training.

(6) Create consciousness among producers and consumers about organic agriculture. The media can play a vital role in increasing awareness about green farming.

(7) Prohibit the use of extremely hazardous pesticides that are banned elsewhere in the world.

(8) Support community seed banks, like the Nayakrishi centres in Bangladesh.

(9) Regional integration between developing countries could bring about breakthroughs in this field.

\section{Limitations and scope for further research}

(1) This study was conducted on a small scale in Dhaka city, but the term 'in Bangladesh' has been used multiple times. To clarify, by 'in Bangladesh', we are not claiming that the results of this study are generalizable to the Bangladeshi population. The term has been used loosely to indicate that the evidence is from Bangladesh. It would be interesting to see how the findings of this study, which was based on data from consumers in Dhaka, would be in case of other cities in Bangladesh. For example, statistics indicate that Chittagong has the highest average per capita 
income in the country (Rahman \& Hossain, 2009). Since the findings of this research indicate that income is the major determinant in organic food consumption, it would have been interesting to see whether consumers living in Chittagong, and with comparatively higher per capita income on average perhaps than consumers living in Dhaka, are more prone towards organic food consumption. Of course, organic food availability, awareness of consumers in Chittagong about the organic-inorganic food issue would have been vital factors to consider. Moreover, there is heterogeneity in consumers' income, awareness level across the different cities of Bangladesh and so, conducting this research in other cities besides Dhaka could add significant dimensions to answering the research question.

(2) The larger the sample size, the closer the approximation of the results to reality; and the better the generalization and external validity of the data. Time constraint disallowed the sample size for this research to be any larger, and perhaps the findings could have been more significant with a larger sample size. Hopefully, there will be scope to conduct the research on a larger scale with more data in the future.

(3) The data collection points in this research were set according to the criteria of stores that sell organic food items alongside inorganic food items. This allowed for the data to incorporate the perceptions of consumers who purchase organic food items from time to time, and also to perceive the factors consumers' base their purchasing decisions on when they have both the choices of organic and inorganic food items available. An interesting dimension could be added to the research by incorporating the perceptions of consumers of grocery stores that do not provide organic food products.

\section{Conclusion}

This research is the first of its kind in the context of Bangladesh and is the first attempt in addressing the research question of whether income constraint is the main determinant behind consumers' decisions to purchase or not purchase organic food products. The findings of this explorative study indicates that the shoppers in the sample have a high level of recognition for organic rice, value its benefits, are willing to pay more for it (except for shoppers earning less than $12 \mathrm{~K}$ taka) but find that it is in short supply and available at only a few markets.

The results of this research show that income constraint is the most major factor affecting the demand for organic rice in Dhaka. The findings suggest that until income levels of consumers increase on a general average level, organic farming will not be a sustainable farming method for Bangladesh. The increase of income level is a gradual process; which is likely to come through Economic growth, which in turn might eventually create a large consumer group and market of organic products. The first step is to raise the general income level of people; because in the beginning, the economic cost of producing organically might force the price of the products to be comparatively higher than the contemporary inorganic products. This situation may change once 
mass production in organic farming is pursued sustainably. Until income level increases on average, it would be unwise to make a big switch on a mass level to organic farming from inorganic- because there is a possibility that the organic market will face the risk of shutdown without enough demand for the market. The switch should be a gradual process, with the increasing of income level being the first priority for the switching mechanism to work efficiently and effectively. It would be a long-term process, which should be immediately started due to the urgency of saving our environment. Food adulteration is also a result of the availability of chemical substances in large amounts in the hands of uneducated unaware farmers, who use the substances in their crops. Unfortunately, moral hazard problem and asymmetric information prevails due to this practice, and thus food adulteration itself has become a large business in Bangladesh now. Switching to an organic farming production system will allow the government to start rationing the amount of chemicals accessible to farmers and businessmen; and authorities will also be able to start enforcing strict laws regarding food adulteration and the use of such harmful substances in crops.

Food security has been a priority for Bangladesh for a long time. The time is approaching, for the sake of saving our environment, for greener farming methods to become our utmost priority. The findings of this study give us hope to look forward to a future where organic farming will become more feasible through the country progressing into a middle-income country. With the economy striving to increase the general income level, let us hope that the day is not far when organic food will become a more normal part of all of our daily lives.

\section{Reference}

(1) Akter, N. (1997). Alternative Agriculture in Bangladesh: a Study of UBINIG, CDA, and PROHIKA Programs. Dhaka: Annual Research Report, Bangladesh Rural Advancement Committee (BRAC).

(2) Asaduzzaman, M. (1996, September 24-25). Resource degradation and sustainable development in Bangladesh: some preliminary estimates. Paper presented in seminar on planning for sustainable development of Bangladesh., Dhaka, Bangladesh.

(3) B.C. Ghosh, \& Bhat, \&. R. (1998). Environmental hazards of nitrogen loading in wetland rice fields. Environmental pollution, 102(1), 123-126.

(4) Barański, M., Średnicka-Tober, D., Volakakis, N., Seal, C., Sanderson, R., Stewart, G. B., et al. (2014). Higher antioxidant and lower cadmium concentrations and lower incidence of pesticide residues in organically grown crops: a systematic literature review and meta-analyses. British Journal of Nutrition, 112(05), 794-811.

(5) Biswas, M. (1994). Agriculture and environment: a review. Ambio , 23 (3), 192-197.

(6) Camargo, J., \& Á. Alonso, \&. (2006). Ecological and toxicological effects of inorganic nitrogen pollution in aquatic ecosystems: a global assessment. Environment international, 32(6), 831-849. 
27 Organic farming: An exploratory study based on evidence from Bangladesh

(7) Capone, R., Bilali, H., Debs, P., Cardone, G., \& Driouech, \&. N. (2014). Food System Sustainability and Food Security: Connecting the Dots. Journal of Food Security, 2(1), 13-22.

(8) D. Bourn, \& Prescott, \&. J. (2002). A comparison of the nutritional value, sensory qualities, and food safety of organically and conventionally produced foods. Critical reviews in food science and nutrition, 42(1), 1-34.

(9) DEFRA. (n.d.) Retrieved 2018, from GOV.UK:

https://www.gov.uk/government/organisations/department-for-environment-food-rural-affairs

(10) Dwyer, M., Kubena, L., Harvey, R., Mayura, K., Sarr, A., Buckley, S., et al. (1997). Effects of inorganic adsorbents and cyclopiazonic acid in broiler chickens. Poultry Science, 76(8), 1141-1149.

(11) Edwards, C. (1989). The importance of integration in sustainable agricultural systems. In M. Paoletti, B. Stinner, \& G. L. (Eds.), Agricultural Ecology and Environment (pp. 25-35). Agric. Ecosyst. Environ.

(12) Gujarati, D., \& Porter, \&. D. (2009). Basic econometrics (5th ed.). Boston: McGraw-Hill.

(13) Hansen, J. (1996). Is agricultural sustainability a useful concept? . Agric. Systems, 50, 117-143.

(14) Heath, A. (1995). Water pollution and fish physiology. CRC press.

(15) Hossain, M. (1988). Nature and Impact of the Green Revolution in Bangladesh . Washington DC: International Food Policy Research Institute \& Bangladesh Institute of Development Studies joint study.

(16) Hossain, S., \& Kashem, M. (1997, July 29). Agronomic management to combat declining soil fertility in Bangladesh. Paper presented in the 6th Biennial Conference of the Bangladesh Society of Agronomy, Dhaka, Bangladesh.

(17) Hossain, S., Salam, M., \& Alam, A. (1994, November 7-10). Farm environment assessment in the context of farming systems in Bangladesh. Third Asian Farming Systems Symposium, Manila, Phillipines.

(18) Hughner, R., McDonagh, P., Prothero, A., Shultz, C. J., \& Stanton, \&. J. (2007). Who are organic food consumers? A compilation and review of why people purchase organic food. Journal of consumer behaviour, 6(2-3), 94-110.

(19) Hughner, R., P. McDonagh, P., Prothero, A., Shultz, C. J., \& Stanton, \&. J. (2007). Who are organic food consumers? A compilation and review of why people purchase organic food. Journal of consumer behaviour, 6(2-3), 94-110.

(20) IFOAM \& FiBL. (2015). World of Organic Agriculture. IFOAM \& FiBL.

(21) IFOAM Annual Report. (2010). Status of Global Organic Market Scenario. IFOAM.

(22) IFOAM. (2006). IFOAM Annual Report. IFOAM. 
Organic farming: An exploratory study based on evidence from Bangladesh

(23) IRRI. (2015). Golden Rice. Retrieved December 18, 2016, from IRRI: International Rice Research Institute: http://irri.org/golden-rice

(24) K. Kumari, Kumar, K., \& Rao, C. (2014). Adverse effects of chemical fertilizers and pesticides on human health and environment. Journal of Chemical and Pharmaceutical Sciences, 150-151.

(25) Magnusson, M., Arvola, A., Hursti, U., Åberg, L., \& Sjödén, \&. P. (2003). Choice of organic foods is related to perceived consequences for human health and to environmentally friendly behaviour. Appetite, 40(2), 109-117.

(26) Martin, H. (2009, December). Introduction to Organic Farming. Retrieved February 23, 2018, from Ministry of Agriculture, Food and Rural Affairs: http://www.omafra.gov.on.ca/english/crops/facts/09-077.htm\#define

(27) Melitz, M., \& Ottaviano, \&. G. (2008). Market size, trade, and productivity. The review of economic studies, 75(1), 295-316.

(28) Newcombe, C., \& MacDonald, \&. D. (1991). Effects of suspended sediments on aquatic ecosystems. North American journal of fisheries management, 11(1), 72-82.

(29) Pimentel, D., Hepperly, P., Hanson, J., Douds, D., \& Seidel, \&. R. (2005). Environmental, energetic, and economic comparisons of organic and conventional farming systems. BioScience, 55(7), 573-582.

(30) Qaim, M., \& Kouser, S. (2015, June 5). Genetically Modified Crops and Food Security. Retrieved December 2, 2016, from PLOS ONE 8(6): https://doi.org/10.1371/journal.pone.0064879

(31) Rahman, S., \& Thapa., G. (1999). Environmental impacts of technological change in Bangladesh agriculture: farmers' perceptions and empirical evidence. . Outlook on Agriculture , 28 (4), 233-238.

(32) Rahman, M. H., \& Hossain, M. S. (2009). Convergence in Per Capita Income across Regions in Bangladesh. The Bangladesh Development Studies Vol. XXXII No.1.

(33) Rahman, M., \& Alam, \&. M. (1997). Risk assessment of pesticides used in Bangladesh. Journal of Civil Engineering, 25(1), 97-106.

(34) Rasul, G., \& Thapa, G. B. (2004). Sustainability of ecological and conventional agricultural systems in Bangladesh: an assessment based on environmental, economic and social perspectives. Agricultural Systems , 327-351.

(35) Sattar, M., \& Mian, A. (1999, June 15-18). Agrochemicals: their effects on crop yields and soil properties. Paper presented in a seminar of Soil Scientist Association on Land Degradation and Soil Pollution, Dhaka, Bangladesh.

(36) Sarker, M., \& Itohara, \&. Y. (2008). Organic farming and poverty elimination: A suggested model for Bangladesh. Journal of Organic Systems, 3(1), 68-79.

(37) Scialabba, N., \& Hattam, \&. C. (2002). Organic agriculture, environment and food security (No. 4). Food \& Agriculture Org.

(38) Shafie, F., \& Rennie, \&. D. (2012). Consumer perceptions towards organic food. Procedia-Social 
29 Organic farming: An exploratory study based on evidence from Bangladesh

and Behavioural Sciences, 49, 360-367.

(39) Shamonti, S. (2012, August 6). Reasons behind slow growth of organic food market in Bangladesh. (R. Murshed, Interviewer)

(40) Steila, D. (1976). The Geography of Soils: Formation, Distribution and Management. New Jersey: Prentice-Hall, Englewood Cliffs.

(41) The Daily Meal. (2012, March 11). 10 reasons organic food is so expensive. Retrieved December 4, 2016, from Fox News: Food and Drinks: http://www.foxnews.com/food-drink/2012/03/11/10reasons-organic-food-is-so-expensive.html

(42) Whelan, J., Msefer, K., \& Chung, \&. C. (2001). Economic supply \& demand. MIT.

(43) Whitman, D. (2000). Genetically modified foods: harmful or helpful? CSA Discovery guides, 113.

(44) Willer, H., \& Yussefi, \&. M. (2005). The world of organic agriculture: Statistics and emerging trends. IFOAM.

(45) Willer, H., Yussefi, M., \& Sorensen, \&. N. (2010). The world of organic agriculture: statistics and emerging trends 2008. Earthscan.

(46) World Bank. (2013). GNI per capita (PPP). Retrieved April 13, 2017, from World Bank: http://data.worldbank.org/indicator/NY.GNP.PCAP.PP.CD

(47) Yiridoe, E., Bonti-Ankomah, S., \& Martin, \&. R. (2005). Comparison of consumer perceptions and preference toward organic versus conventionally produced foods: a review and update of the literature. Renewable Agriculture and Food Systems, 20(04), 193-205.

(48) Yunlong, C., \& Smith, B. (1994). Sustainability in agriculture: a general review. Agric. Ecosyst. Environ. , 49, 299-307.

(49) Zanoli, R., \& Naspetti, \&. S. (2002). Consumer motivations in the purchase of organic food: a means-end approach. British food journal, 104(8), 643-653.

\section{Annex}

Annex no. 1

\begin{tabular}{|c|c|c|c|}
\hline \multirow{2}{*}{$\begin{array}{c}\text { Consumer's } \\
\text { characteristics }\end{array}$} & $\begin{array}{c}\text { Distribution of the consumers } \\
\text { based on their characteristics }\end{array}$ & $\begin{array}{c}\text { Number of consumers } \\
(\mathrm{n}=120)\end{array}$ & Percentage of consumers \\
\hline Age(years) & Young(below 35) & 43 & $35.83 \%$ \\
\cline { 2 - 4 } & Middle aged(36-50) & 66 & $9.166 \%$ \\
\cline { 2 - 4 } & Old(above 50) & 11 & $55 \%$ \\
\hline
\end{tabular}


30 Organic farming: An exploratory study based on evidence from Bangladesh

Annex no.2: Occupation distribution of the consumers

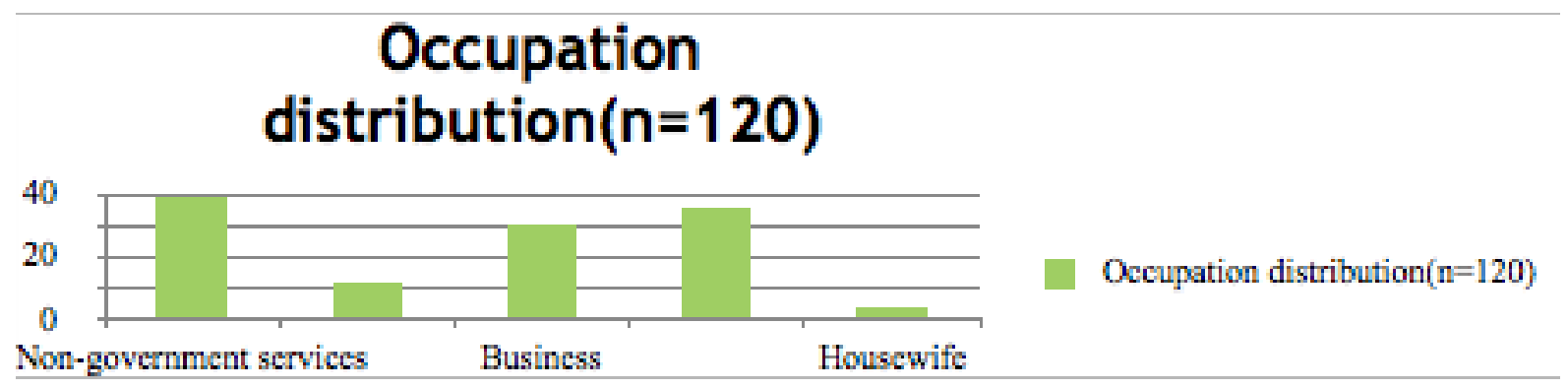

Annex no.3: Educational levels of consumers

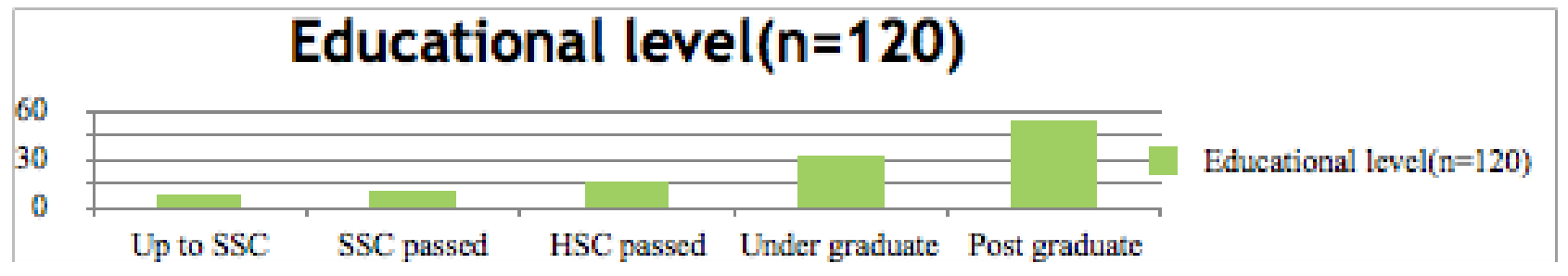

Annex no.4: Multicollinearity Test

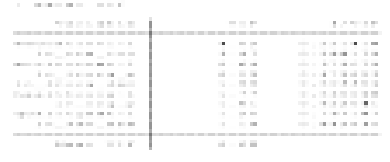

Annex no.5: Specification Bias Test

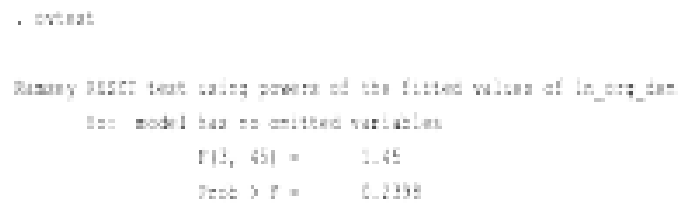

Annex no.6: Heteroscedasticity Test

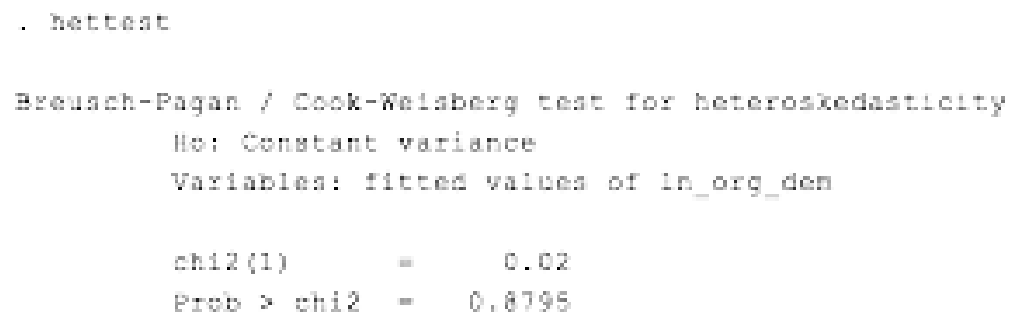

